\title{
Our double valve replacement strategy in a case with pectus carinatum deformity
}

\author{
L Yilik, K Ergunes, U Yetkin", I Peker, I Yurekli, E Celik, A Gurbuz \\ From 23rd World Congress of the World Society of Cardio-Thoracic Surgeons \\ Split, Croatia. 12-15 September 2013
}

\section{Background}

Pectus carinatum is a deformity of the chest characterized by a protrusion of the sternum and ribs. It develops as a result of an overgrowth of cartilage causing the sternum to protrude forward. It is detected most commonly during pubertal growth spurt.

\section{Methods}

Our case was a 63-year-old male. An elective umbilical hernia repair was being planned. During the investigations due to shortness of breath, transthoracic echocardiography (TTE) revealed severe aortic and mitral regurgitation. Left ventricular end-diastolic and end-systolic diameters were measured as 72 and $48 \mathrm{~mm}$, respectively. Left and right atrial diameters were measured as 56 and $55 \mathrm{~mm}$, respectively. Pulmonary arterial pressure was calculated as $35 \mathrm{~mm} \mathrm{Hg}$ and left ventricular ejection fraction was identified as $60 \%$. Coronary angiography detected no significant stenoses and confirmed aortic and mitral regurgitation with an ejection fraction of $50 \%$. Our case was consulted with Department of Pulmonary Diseases due to dyspnea and moderate pectus carinatum. Fibrotic lesions and pleural thickenings in the upper zones of both hemithoraces were interpreted as sequelae of tuberculosis. Pulmonary function tests were normal. Elective open heart surgery was planned.

\section{Results}

After standard median sternotomy, aortic valve was replaced with $23 \mathrm{~mm}$ St. Jude mechanical valve and mitral valve was replaced with $31 \mathrm{~mm}$ St. Jude mechanical valve. Left atrial appendix was sutured internally due to

\footnotetext{
* Correspondence: ufuk_yetkin@yahoo.fr

Department of Cardiovascular Surgery, Izmir Katip Celebi University Ataturk Training and Research Hospital, Izmir, Turkey
}

atrial fibrillation to avoid embolization and posterior leaflet of the mitral valve was preserved. Postoperative period was event-free.

\section{Conclusions}

Most cases with pectus carinatum are asymptomatic as in our case. Psychological and cosmetic disturbances may be observed as well as respiratory tract infections and exertional dyspnea. We think that technically challenging correction surgery should be avoided if patients are asymptomatic, particularly after completion of calcification process of the bony structures.

Published: 11 September 2013

\section{doi:10.1186/1749-8090-8-S1-P21}

Cite this article as: Yilik et al:: Our double valve replacement strategy in a case with pectus carinatum deformity. Journal of Cardiothoracic Surgery 2013 8(Suppl 1):P21.
Submit your next manuscript to BioMed Central and take full advantage of:

- Convenient online submission

- Thorough peer review

- No space constraints or color figure charges

- Immediate publication on acceptance

- Inclusion in PubMed, CAS, Scopus and Google Scholar

- Research which is freely available for redistribution
() Biomed Central
C Biomed Central

() 2013 Yilik et al; licensee BioMed Central Ltd. This is an Open Access article distributed under the terms of the Creative Commons Attribution License (http://creativecommons.org/licenses/by/2.0), which permits unrestricted use, distribution, and reproduction in any medium, provided the original work is properly cited. 